\title{
Human Intestinal Epithelial Cells Express Interleukin-10 through Toll-Like Receptor 4-Mediated Epithelial-Macrophage Crosstalk
}

\author{
Jinhee Hyun ${ }^{a} \quad$ Laura Romero $^{a}$ Reldy Riveron ${ }^{a} \quad$ Claudia Flores $^{c}$ \\ Saravana Kanagavelu ${ }^{\text {a, c }}$ Kristina D. Chung ${ }^{a}$ Ana Alonso $^{a}$ John Sotolongo ${ }^{a}$ \\ Jose Ruiz ${ }^{a}$ Armine Manukyan $^{c}$ Sally Chunc Gaurav Singh ${ }^{\mathrm{a}}$ Pedro Salas $^{\mathrm{b}}$ \\ Stephan R. Targan ${ }^{c}$ Masayuki Fukata ${ }^{a-c}$ \\ ${ }^{a}$ Division of Gastroenterology, Department of Medicine, and ${ }^{b}$ Department of Cell Biology, University of Miami Miller \\ School of Medicine, Miami, Fla., and 'Division of Gastroenterology, Department of Medicine, F. Widjaja Foundation, \\ Inflammatory Bowel and Immunology Research Institute, Cedars-Sinai Medical Center, Los Angeles, Calif., USA
}

\section{Key Words}

Epithelial cells $\cdot$ Interleukin-10 $\cdot$ Intestine $\cdot$ Macrophages .

Peroxisome proliferator-activated receptor $\cdot$ Toll-like receptors

\begin{abstract}
In the intestine, interaction between epithelial cells and macrophages (MФs) create a unique immunoregulatory microenvironment necessary to maintain local immune and tissue homeostasis. Human intestinal epithelial cells (IECs) have been shown to express interleukin (IL)-10, which keeps epithelial integrity. We have demonstrated that bacterial signaling through Toll-like receptor (TLR) 4 induces 15 -deoxy$\Delta$-12,14-prostaglandin J2 (15d-PGJ2) synthesis in intestinal MФs by cyclooxygenase (Cox)-2 expression. Here, we show that TLR4 signaling generates crosstalk between IECs and $M \Phi s$ that enhances IL-10 expression in IECs. Direct stimulation of TLR4 leads to the expression of IL-10 in IECs, while the presence of MФs in a Transwell system induces another peak in IL-10 expression in IECs at a later time point. The second peak of the IL-10 expression is two times greater than the first peak. This late induction of IL-10 depends on the nuclear receptor peroxisome proliferator-activated receptor
\end{abstract}

(PPAR) $y$ that is accumulated in IECs by TLR4-mediated inhibition of the ubiquitin-proteasomal pathway. TLR4 signaling in MФs in turn synthesizes 15d-PGJ2 through p38 and ERK activation and Cox-2 induction, which activates PPARY in IECs. These results suggest that TLR4 signaling maintains IL10 production in IECs by generating epithelial-MФs crosstalk, which is an important mechanism in the maintenance of intestinal homeostasis mediated through host-bacterial interactions.

(c) 2014 S. Karger AG, Basel

\section{Introduction}

Intestinal mucosal immune responses to commensal bacteria are continuously controlled by endogenous immunoregulatory mechanisms. As an interface between host and commensal bacteria, intestinal epithelial cells (IECs) play crucial roles in keeping mucosal homeostasis largely through the regulation of innate immunity. The loss of this homeostasis results in chronic inflammation of mucosa seen in inflammatory bowel diseases (IBDs). Toll-like receptors (TLRs) are major innate immune receptors that induce cellular and molecular signaling path- 
ways to maintain intestinal epithelial integrity by recognizing pathogen-associated molecular patterns of luminal microbes $[1,2]$. This response is particularly important when the mucosal barrier is disrupted following exposure of the basolateral aspect of IECs and lamina propria immune cells to microbial products where TLRs may be activated [3]. Leakage of the epithelial barrier is known to occur frequently in intestinal mucosa even upon psychological stress and predisposes to irritable bowel diseases and IBD $[4,5]$. While the inflammatory responses that may be triggered against commensal flora are regulated in healthy intestinal mucosa, underlying mechanisms of the regulation remain to be fully understood.

Interleukin 10 (IL-10) is one of the major anti-inflammatory cytokines required to control host immune responses to intestinal bacteria since IL-10-deficient mice develop spontaneous colitis only in the presence of commensal bacteria $[6,7]$. IL-10 has not only been shown to suppress proinflammatory signaling, but also to maintain intestinal epithelial barrier function $[8,9]$. Although IL10 reporter knockin mice have demonstrated the absence of IL-10 expression in IECs, IECs have been identified as the major cell type expressing IL-10 in normal human intestine $[10,11]$. This expression of IL-10 by IECs appears to be physiologically indispensable for epithelial homeostasis. This conclusion is supported by the fact that blocking IL-10 production by IECs leads to a disruption of the epithelial lining in the human intestine due to excessive apoptosis and IFN- $\gamma$ production [9]. Interestingly, the production of IL-10 from IECs is not observed in germfree rats, but it is induced after colonization of commensal bacteria [12]. Therefore, bacterial signaling is likely involved in the homeostatic IL-10 production in IECs. Moreover, oral administration of chitosan, a type of oligosaccharide that acts as TLR4 ligand to rats, has been shown to induce IL-10 from IECs [13]. These findings suggest that IL-10 production from human IECs may be regulated by mucosal TLR 4 signaling in response to luminal commensal bacteria.

We have demonstrated that TLR4 signaling regulates anti-inflammatory 15 -deoxy- $\Delta$-12,14-prostaglandin $\mathrm{J} 2$ (15d-PGJ2) synthesis in the intestine via cyclooxygenase-2 (Cox-2) induction in subepithelial macrophages (MФs) [14]. The significance of TLR signaling-dependent Cox-2 induction in subepithelial MФs in IEC homeostasis has been reported in a mouse mucosal injury model $[15,16]$, but whether this regulation of IEC homeostasis is involved in IL-10 production from IECs has not been studied. 15dPGJ2 is an endogenous ligand of the nuclear receptor peroxisome proliferator-activated receptor (PPAR) $\gamma$, which possesses anti-inflammatory properties known to antagonize NF- $\kappa B, A P-1$ and STAT1 [17-19]. PPAR $\gamma$ can be expressed by many cell types in humans, but adipocytes and IECs are known to be the two major cell types that abundantly express PPAR $\gamma$ [20]. It has been shown that exposure of human IECs to Enterococcus faecalis isolated from the human intestine results in the activation of PPAR $\gamma$ and IL-10 production in IECs [21]. Furthermore, TLR4 signaling may induce PPAR $\gamma$ expression in IECs $[22,23]$. These data suggest that epithelial PPAR $\gamma$ integrates mucosal TLR4 signaling to IL-10 production in IECs.

In this study, we examined TLR4-mediated crosstalk between IEC and MФs that induces IL-10 production in IECs via PPAR $\gamma$ activation. Co-culturing of polarized IECs with MФs resulted in late but enhanced IL-10 production by IECs in response to TLR4 stimulation. This late induction of IL-10 in IECs was not observed without MФ TLR4 signaling. The crosstalk between MФs and IECs was mediated by the induction of 15d-PGJ2 synthesis in MФs. On the other hand, PPAR $\gamma$ expression, nuclear accumulation and DNA binding activities in IECs were observed prior to the enhanced IL-10 production. Blocking PPAR $\gamma$ expression or activation in IECs completely abolished the late IL-10 production. Moreover, we detected a PPAR $\gamma$ binding site in the human IL-10 (hIL-10) promoter region that was responsible for the late IL-10 expression in IECs. These results indicate that TLR4-dependent host-commensal interactions maintain the IL-10 production from IECs through 15d-PGJ2 synthesis in subepithelial MФs and consequent activation of PPAR $\gamma$ in IECs. This may be an intrinsic immunoregulatory program that maintains mucosal homeostasis in dynamic fluctuations of epithelial permeability and in the presence of dense luminal bacteria.

\section{Materials and Methods}

Isolation of Human IECs and Lamina Propria MФs

Human colon specimens were obtained from surgical resection of normal margins of colon cancer in otherwise healthy individuals with the approval of the Institutional Review Board at the CedarsSinai Medical Center. The mucosal layer was dissected from the specimens and vigorously shaken in $\mathrm{Ca}^{2+}-\mathrm{Mg}^{2+}$-free HBSS containing $2 \mathrm{~mm}$ EDTA for $20 \mathrm{~min}$ at $37^{\circ} \mathrm{C}$. Epithelial cells were purified from the supernatant with a $30 \%$ Percoll gradient centrifugation. Epithelial cells were further enriched by negatively depleting intraepithelial lymphocytes with magnetic beads using anti-CD45$\mathrm{PE}$ and a lineage depletion kit (Miltenyi Biotec). Lamina propria mononuclear cells were isolated as previously described [24]. Lamina propria $\mathrm{M} \Phi$ s were further purified from lamina propria mononuclear cells by magnetic sorting with anti-human CD64-PE and anti-PE microbeads (Miltenyi Biotec). Purified lamina propria
88

J Innate Immun 2015;7:87-101 DOI: $10.1159 / 000365417$
Hyun et al. 
MФs were incubated in Dulbecco's modified Eagle's medium containing $10 \%$ (vol/vol) FBS and 1\% (vol/vol) penicillin-streptomycin in a 96-well plate at the concentration of $5 \times 10^{4}$ cells/well for $48 \mathrm{~h}$ in the presence or absence of lipopolysaccharide (LPS; $500 \mathrm{ng} /$ $\mathrm{ml})$. Supernatants were measured for $15 \mathrm{~d}-\mathrm{PGJ} 2$.

\section{RT-PCR}

Total RNA was extracted from purified human IECs with RNA-Bee (Tel-Test), and cDNA was amplified using a QuantiTect reverse transcription kit (Qiagen) according to the manufacturer's instructions. For PCR amplifications, we used a Phusion high-fidelity PCR mix (New England Biolabs). Primers for IL-10 were designed from the sequence from GenBank (NM 000572): sense $5^{\prime}$-CAGCTCAGCACTGCTCTGTTG- ${ }^{\prime}$ and antisense $5^{\prime}$-CTCC AGCAAGGACTCCTTTAAC- $3^{\prime}$. The size of the PCR product was $211 \mathrm{bp}$. The amplification was done by $30 \mathrm{~s}$ denaturation at $98^{\circ} \mathrm{C}$ and $8 \mathrm{~s}$ annealing at $60.5^{\circ} \mathrm{C}$ for 35 cycles. Primers and amplification protocols for CD45 and $\beta$-actin have been described previously $[25,26]$ : CD 45 sense $5^{\prime}$-CTGACATCATCACCTAGCAG-3' and antisense $5^{\prime}$-TGCTGTAGTCAATCCAGTGG-3' (product size $257 \mathrm{bp}$ ) and $\beta$-actin sense $5^{\prime}$-CATCCTCACCCTGAAGT ACC- $3^{\prime}$ and antisense $5^{\prime}$-GCTCATTGTAGAAGGTGTGG-3' (product size $92 \mathrm{bp}$ ). Other primers used were human TLR4 sense $5^{\prime}$-GCATTTAACTCACTCTCCAGTC- $3^{\prime}$ and antisense $5^{\prime}$-CAT CCTGGCTTGAGTAGATAAC-3' (product size $511 \mathrm{bp}$ ) and human PPAR $\gamma$ sense $5^{\prime}$-TCTCTCCGTAATGGAAGACC- $3^{\prime}$ and antisense $5^{\prime}$-GCATTATGAGACATCCCCAC-3' (product size 482 bp). PCR products were visualized on a $2 \%$ agarose gel under ultraviolet light.

\section{Cell Lines and Reagents}

Human IEC lines SW480-APC and Caco-2 were kindly provided by Dr. Maree C. Faux (Ludwig Institute for Cancer Research, Australia) and Dr. Pedro Salas (University of Miami), and maintained on $12-\mathrm{mm}$ Transwells (Sigma) with $0.4-\mu \mathrm{m}$ pore carbonate membrane insert, as previously described $[27,28]$. LPS (500 ng/ml, phenol-water-extracted Escherichia coli K235; Sigma) was added to the bottom wells for the indicated periods. Hydrocortisone was removed during LPS stimulation in SW480-APC cells. Inhibitors for PPAR $\gamma$ (SR202; R\&D Systems), MAP kinases (SB203580, SP600125 and PD98059; Sigma), PI3 kinase (LY294002; Millipore) and Cox-2 (NS-398; R\&D Systems) were added 90 min prior to LPS stimulation.

\section{Isolation of Peritoneal MФs and Co-Culture with IEC}

In order to distinguish epithelial versus M $\Phi$ IL-10 production, we utilized an in vitro co-culture model of human IECs and mouse MФs. Wild-type (WT) and TLR4-/- mice on C57Bl6 background were maintained in the animal care facility at the Division of Veterinary Resources (University of Miami). All experiments described in this study have been approved by the University of Miami Institutional Animal Care and Use Committee. MФs were isolated from peritoneal lavage of WT and TLR4-/- mice using sterile PBS and seeded onto 12-well plates at a density of $2.5 \times 10^{5}$ cells/well with Dulbecco's modified Eagle's medium containing $10 \%$ FBS and $1 \%$ penicillin-streptomycin (Invitrogen). In the meantime, human IEC lines SW480-APC or Caco-2 cells were grown on the Transwell inserts to form a monolayer. Monolayered cells were co-cultured with or without peritoneal MФs in the Transwell system.

TLR4 Mediates PPAR $\gamma$-Dependent IL-10 Production in Human IECs

\section{Real-Time PCR}

Total RNA was isolated using RNA Bee according to the manufacturer's instructions. Single-strand cDNA was synthesized from $1 \mu \mathrm{g}$ RNA using a QantiTect reverse transcription kit (Qiagen) according to the manufacturer's instructions. Quantitative real-time PCR was performed with LightCycler 480 using SYBR Premix Ex Taq (Thermo). The following primers were used: for human PPAR $\gamma$, sense primer $5^{\prime}$-ATCTTTCAGGGCTGCCAGT-3' and antisense primer $5^{\prime}$-AGTGTCTCATACGGTTTTCGT- $3^{\prime}$; for IL-10, sense primer $5^{\prime}$-GCCTAACATGCTTCGAGATC- $3^{\prime}$ and antisense primer $5^{\prime}$-AGTGTCTCATACGGTTTTCGT-3' ${ }^{\prime}$, and for $\beta$-actin, sense primer $5^{\prime}$-CAT CCT CAC CCT GAA GTA CC-3' and antisense primer $5^{\prime}$-GCT CAT TGT AGA AGG TGT GG- $3^{\prime}$. Relative expression levels were calculated with the comparative $2^{-\Delta \Delta C t}$ method using $\beta$-actin as the endogenous control.

\section{RNA Interference}

Small interfering RNA (siRNA; 50) oligonucleotides against PPAR $\gamma$ (sc-29455; Santa Cruz Biotechnology) were transfected into Caco- 2 cells in a 12 -well plate $\left(1.5 \times 10^{5}\right.$ cells/well $)$ using the Lipofectamine RNAiMax transfection reagent (Invitrogen). Control cells were transfected with AllStars negative control siRNA (Qiagen). The knockdown efficiency of PPAR $\gamma$ siRNA was confirmed by Western blotting.

\section{Western Blot Analysis}

Whole cell lysates were prepared from SW480-APC and Caco2 cells using RIPA lysis buffer (Pierce Biotechnology) with a proteinase inhibitor cocktail (Calbiochem). Twenty five micrograms of the lysates were subjected to $10 \%$ SDS-PAGE and transferred to nitrocellulose membranes (Bio-Rad). The membrane was blocked with $5 \%$ skim milk and was immunoblotted with the primary antibodies overnight at $4^{\circ} \mathrm{C}$. Primary antibodies used are rabbit antimurine Cox-2 (Cayman), rabbit anti-human PPAR $\gamma$ (H-100; Santa Cruz Biotechnology) and rabbit anti- $\beta$-actin (Cell Signaling). HRP-conjugated donkey anti-rabbit IgG (Promega) was used as secondary antibody. The membrane was exposed on an X-ray film using an enhanced chemiluminescent substrate SuperSignal West Dura kit (Pierce Biotechnology).

\section{Immunoprecipitation}

SW480-APC cell lysate $(400 \mu \mathrm{g})$ was incubated with protein A/G plus agarose to exclude nonspecifically binding proteins (Santa Cruz Biotechnology). The liquid component was incubated with anti-PPAR $\gamma$ antibody (H-100) or control normal rabbit IgG overnight at $4^{\circ} \mathrm{C}$. Samples were then incubated with protein A/G plus agarose for $2 \mathrm{~h}$ and washed with ice-cold PBST (PBS $+0.05 \%$ Tween 20) 4 times followed by washing with ice-cold PBS. Precipitates were boiled in Laemmli sample buffer (Bio-Rad) and subjected to Western blot analysis using HRP-conjugated anti-ubiquitin (Ub) monoclonal antibody (Santa Cruz Biotechnology).

\section{hIL-10 Promoter Cloning}

Genomic DNA of SW480-APC cells was purified using an EZNA tissue DNA kit (Omega Bio-Tek) and was used as a template. Specific primers bearing restriction enzyme sites $(-2,000$ sense $5^{\prime}$-CCGCTAGCCGAGGGGGAAGGAGA-3', $-1,000$ sense $5^{\prime}$-CCGCTAGCCTCCAGCCACAGAAG-3', -500 sense $5^{\prime}$-CCG CTAGCTTAGCAAGGAGAAGT-3', -400 sense $5^{\prime}$-CCGCTAG CGAACACGCGAATGAGA- ${ }^{\prime}$ and +110 antisense $5^{\prime}$-GGCTC 
GAGAGGTTGCCTGGGA-3') were used to generate a series of hIL-10 promoter fragments. The PCR fragments were inserted into pGL3 basic vector (Promega) via XhoI and NheI sites and ligation mixtures were delivered to JM109 as per manufacturer's instructions (Promega). Positive clones were selected and verified by DNA sequencing.

Transient Gene Expression and Reporter Assays

SW480-APC cells were plated in 12-well plates at a density of $1.5 \times 10^{5}$ cells/well. Reporter genes of PPAR response elements (PPRE; X3-TK-luc) that contain three copies of PPRE (Addgene), IL-10 promoter-luciferase constructs and pGL3 basic empty vector were individually co-transfected with pRL-TK (Promega) using Lipofectamine transfection reagent (Invitrogen) as per manufacturer's instructions. After overnight transfection, cells were trypsinized and transferred into 12-well Transwell inserts and grown in monolayer for $48 \mathrm{~h}$. After LPS stimulation, cells were lysed with CCLR lysis buffer (Promega) and luciferase activity was measured with a Dual-Luciferase Reporter Assay (Promega). Luciferase measurements were normalized to the relative light units from Renilla luciferase from pRL-TK. Data are reported as percent increase over control samples (no LPS or pGL3 basic empty vector samples).

\section{Chromatin Immunoprecipitation}

SW480-APC cells and mouse peritoneal MФs were prepared in the Transwell system as described above. After $48 \mathrm{~h}$ of LPS stimulation in the bottom wells, SW480-APC cells were harvested, and DNA and protein were cross-linked in situ with $0.5 \%(\mathrm{v} / \mathrm{v})$ formaldehyde at $37^{\circ} \mathrm{C}$ for $5 \mathrm{~min}$. Soluble chromatin was prepared using a ChIP-IT high-sensitivity kit (Active Motif). The lysates were precipitated with anti-PPAR $\gamma(\mathrm{H}-100)$ or control normal rabbit IgG and protein G/A-agarose beads after sonication. DNA was purified from the precipitates and eluted DNA was amplified with sense $5^{\prime}$-CCGCTAGCTTAGCAAGGAGAAGT- ${ }^{\prime}$ and antisense $5^{\prime}$-GGCTCGAGAGGTTGCCTGGGA-3' primers that flanked the PPRE site of the hIL-10 promoter. PCR products were analyzed in $2.5 \%$ agarose gel.

\section{Immunofluorescence Analysis}

SW480-APC cells and mouse peritoneal MФs were prepared in the Transwell system and stimulated with LPS for the indicated periods. SW480-APC cells on the Transwell membrane were washed with PBS and fixed in 2\% paraformaldehyde overnight at $4^{\circ} \mathrm{C}$. Cells were then permeabilized with $0.2 \%$ Triton X-100 (Sig$\mathrm{ma}$ ). After blocking with $10 \%$ normal goat serum for $1 \mathrm{~h}$, cells were incubated with anti-PPAR $\gamma$ antibody (H-100) diluted in PBS containing $1 \%$ BSA (1:200) overnight at $4^{\circ} \mathrm{C}$. After washing with PBS, cells were incubated with Alexa Fluor 488-conjugated goat antirabbit IgG (Invitrogen) diluted in PBS containing 1\% BSA (1:400) for $90 \mathrm{~min}$ at room temperature. Nuclei were stained with DAPI (4',6-diamidino-2-phenylindole, dihydrochloride; Sigma). After washing with PBS, cells in the Transwell membrane were removed and placed on glass slides. Slides were then mounted with ProLong gold antifade reagent (Invitrogen) and analyzed with an EVOS fluorescent microscope (Advanced Microscopy Group).

\section{Measurement of $15 d-P G J 2$ and IL-10 Protein}

Production of 15d-PGJ2 was determined in the cell culture supernatants using EIA kit (Enzo Life Sciences) according to the manufacturer's instructions. Protein levels of hIL-10 and mouse

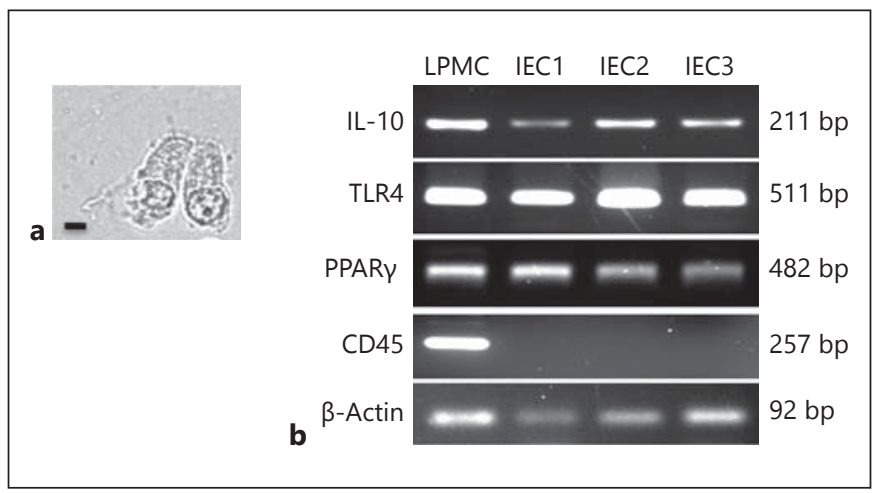

Fig. 1. Human primary IECs express IL-10. a Morphological observation of isolated IECs. Representative picture of IECs observed under the phase contrast light microscope is shown (original magnification $\times 40$, bar $=5 \mu \mathrm{m}$ ). $\mathbf{b}$ RT-PCR analysis of mRNA expression of human IL-10, TLR4 and PPAR $\gamma$ in isolated IECs. Three independent IEC samples are shown (lanes 2-4). Lamina propria mononuclear cells (LPMCs, lane 1) were used as a control to prove no contamination with hematopoietic cells showing CD45 mRNA expression (middle panel).

IL-10 were determined in culture media using a DuoSet ELISA Development System (R\&D Systems) following the manufacturer's instructions.

\section{Statistical Analysis}

Student's t test for the comparison of two independent samples and one-way ANOVA for more than two independent samples were performed using GraphPad Prism (version 5.0b); a value of $\mathrm{p}<0.05$ was considered statistically significant.

\section{Results}

\section{Human Primary Colonic Epithelial Cells Express \\ IL-10 mRNA}

Previous reports have shown the expression of IL-10 in human colonic IECs by immunohistochemistry and in situ hybridization [9, 11]. In our study, we first confirmed mRNA expression of IL-10, TLR4 and PPAR $\gamma$ in isolated primary human IECs in the colon. Colonic IECs were purified from surgical operation samples. We confirmed the homogenous morphology of cells that represented the columnar cell phenotype (fig. 1a). Consequent analysis of human IL-10, TLR4 and PPAR $\gamma$ mRNA in those samples demonstrated substantial expression of these genes, while CD45 mRNA expression was negative confirming no immune cell contamination (fig. 1b). These results substantiate that normal human IECs express IL-10.
90 


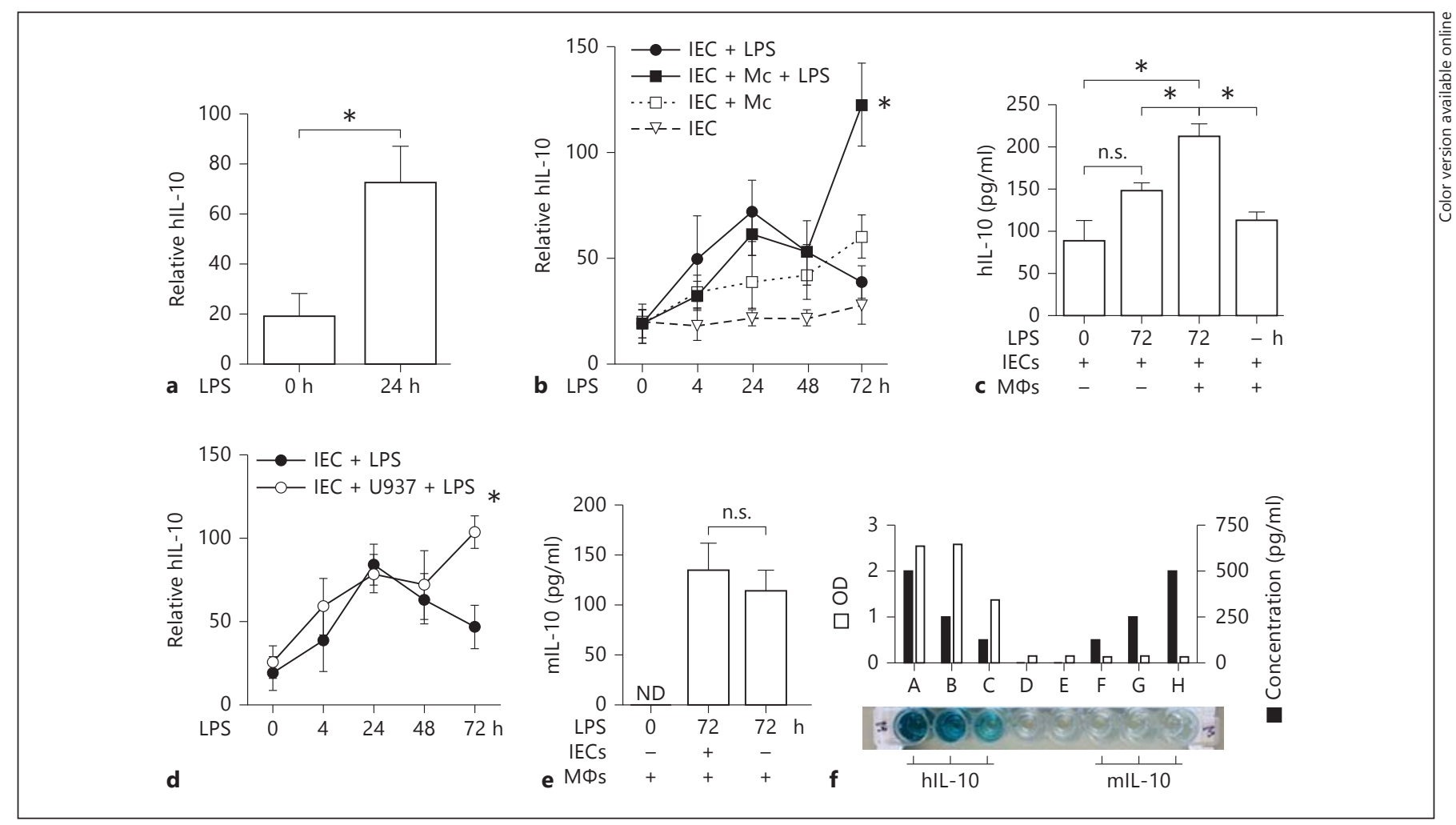

Fig. 2. Presence of $M \Phi s$ amplifies IL-10 production by human IECs in response to LPS. a Real-time PCR results of IL-10 mRNA expression in SW480-APC cells grown in conventional wells. Cells were stimulated with LPS for the indicated periods. The relative expression of hIL-10 to $\beta$-actin is shown. Data from three independent experiments of triplicate samples with SEM $(* \mathrm{p}<0.05)$. b Real-time PCR results of IL-10 mRNA expression in polarized SW480-APC cells (IEC) in the Transwell system. Cells were basolaterally stimulated with LPS for the indicated periods. One series of polarized SW480-APC cells (inserts) were co-cultured with mouse peritoneal MФs (bottom wells). Dotted lines show results from LPS-non-treated controls. The relative expression of hIL-10 to $\beta$-actin is shown. Data from three independent experiments of triplicate samples with SEM $\left({ }^{*} \mathrm{p}<0.05\right)$. c IL-10 production from polarized SW480-APC cells with or without co-culturing with mouse peritoneal MФs in the Transwell system. Cells were basolaterally stimulated with LPS as indicated. hIL-10 concentration in the bottom wells was measured by specific ELISA. Data from three

\section{MФs Enhance IL-10 Production from Human IECs during LPS Stimulation}

The physiological relevance of the expression of IL-10 in IECs has been shown in ex vivo human intestinal mucosal culture [9]. In this study, we used SW480-APC cells as an IEC line because it polarizes on the Transwell and expresses functional TLR4 [27]. TLR4 stimulation of this cell line in the conventional wells resulted in a significant increase in IL-10 mRNA expression in $24 \mathrm{~h}$ (fig. 2a). In a independent experiments of duplicate samples with SEM $(* \mathrm{p}<$ 0.05). d Real-time PCR results of IL-10 mRNA expression in polarized SW480-APC cells during co-culturing with human monocyte/MФ line U937 cells in the Transwell system. Cells were basolaterally stimulated with LPS for the indicated periods. The relative expression of hIL-10 to $\beta$-actin is shown. Data from three independent experiments of triplicate samples with SEM $\left({ }^{*} p<0.05\right)$. e IL-10 production from mouse peritoneal $\mathrm{M} \Phi$ s during co-culture with SW480-APC cells in the Transwell system. Cells were basolaterally stimulated with LPS as indicated. Mouse IL-10 (mIL-10) concentration in the bottom wells was measured by specific ELISA. Data from two independent experiments of duplicate samples with $\operatorname{SEM}\left({ }^{*} p<0.05\right)$. $f$ ELISA detection of hIL- 10 without cross-reaction to mouse IL-10. Black bars show concentration of IL-10 (human: wells A, B, C, mouse: wells F, G, H) added and white bars show optical density (OD) measured by a spectrophotometer. Wells D and E received no IL-10 (background).

time course experiment, polarized SW480-APC cells showed a significant increase in IL-10 expression, which peaked $24 \mathrm{~h}$ after basolateral stimulation with LPS. When we co-cultured polarized SW480-APC cells with peritoneal MФs in Transwells, IL-10 expression by IECs had another peak at $72 \mathrm{~h}$ of basolateral LPS stimulation, which was two times greater than the original peak at $24 \mathrm{~h}$ (fig. 2b). This enhancement in IL-10 expression by $M \Phi$ co-culture was also confirmed at the protein level (fig. 2c). 
The late induction of IL-10 mRNA by IECs was also observed when we co-cultured polarized SW480-APC cells with the human monocyte/MФ cell line U937 (fig. 2d). On the other hand, the production of IL-10 from MФs in response to LPS stimulation did not change by co-culturing with IECs (fig. 2e). Our experimental system co-culturing polarized human IECs with mouse peritoneal MФs is advantageous to distinguish IEC IL-10 production from $M \Phi$ IL-10 production (fig. $2 \mathrm{f}$ ). Therefore, these results suggest that the expression of IL-10 from human IECs is induced by humoral substances from $M \Phi$ s during LPS exposure.

MФ TLR4 Signaling Induces Anti-Inflammatory Prostaglandin 15d-PGJ2 during Co-Culturing with IECs

Next we tried to identify the humoral substance produced by MФs in response to LPS. We have shown that one of the major intestinal phenotypes of TLR4-deficient mice is impaired expression of Cox-2 in subepithelial MФs [14, 29]. The decreased Cox-2 induction results in defective mucosal synthesis of anti-inflammatory $15 \mathrm{~d}$ PGJ2 during mucosal injury [14]. Since 15d-PGJ2 is known to support the expression of anti-inflammatory cytokines by inhibiting intracellular proinflammatory pathways, we tested whether 15d-PGJ2 was produced by MФs in response to LPS. Stimulation of MФs with LPS during co-culturing with IECs resulted in a significant induction of 15d-PGJ2 in the bottom wells (i.e. by MФs) at the peak of $48 \mathrm{~h}$ (fig. 3a). We confirmed that $М \Phi$ s were the major source of $15 \mathrm{~d}-\mathrm{PGJ} 2$ in our co-culture system as we observed a consistent concentration of 15d-PGJ2 regardless of the presence or absence of IECs (fig. 3b). Furthermore, 15d-PGJ2 production was not observed when we used TLR4-deficient MФs (fig. 3c). The inhibition of Cox-2 (by NS398) or MAP kinases p38 (by SB203580) and ERK (by PD98059) individually suppressed 15d-PGJ2 production by MФs, while 15d-PGJ2 production was independent of JNK (SP600125) and PI3 kinases (LY294002; fig. 3c). Corresponding to the 15d-PGJ2 production, we confirmed Cox-2 induction in MФs within $24 \mathrm{~h}$ of LPS stimulation (fig. 3d). Furthermore, we observed substantial induction of 15d-PGJ2 in freshly isolated primary human colonic MФs after stimulation with LPS (fig. 3e).

In contrast to 15d-PGJ2, mRNA expression of the proinflammatory cytokine TNF- $\alpha$ was rapidly induced by MФs within $4 \mathrm{~h}$ of LPS stimulation and TNF- $\alpha$ induction was down-regulated after $24 \mathrm{~h}$ (fig. 3f). This induction of MФ TNF- $\alpha$ was significantly suppressed when co-cultured with IECs. Induction of TNF- $\alpha$ mRNA expression from IECs was not observed after LPS stimulation (data not shown). These results indicate that MФs induce antiinflammatory 15d-PGJ2 in response to LPS through TLR4-mediated Cox-2 induction which requires p38 and ERK MAP kinase activation. By contrast, TLR4-mediated expression of proinflammatory TNF- $\alpha$ in MФs is rapid and transient, which may be down-regulated by co-culturing with IECs.

\section{LPS Stimulation Induces PPAR Activation in Human}

IECs during Co-Culturing with $M \Phi$ s

Prostaglandins are functionally conserved among species and 15d-PGJ2 is a natural ligand of PPAR $\gamma[30,31]$. We tested whether the 15d-PGJ2 produced by mouse MФs activates PPAR $\gamma$ in human IECs. First, we confirmed the protein expression of PPAR $\gamma$ in our IEC line SW480-APC. Western blot analysis demonstrated an increase in PPAR $\gamma$ protein expression in IECs after stimulation with LPS (fig. 4a). There was no significant difference in the expression of PPAR $\gamma$ mRNA after LPS stimulation (Figure $4 \mathrm{~b}$ ). In contrast, ubiquitination of PPAR $\gamma$ protein was reduced by $24 \mathrm{~h}$ after LPS stimulation (fig. 4c). Therefore, the increased expression of PPAR $\gamma$ protein was not likely to be corresponding with PPAR $\gamma$ mRNA induction but rather associated with reduced degradation of PPAR $\gamma$ protein.

Next, we examined PPAR $\gamma$ activation in IECs during co-culturing with MФs. SW480-APC cells were transfected with a PPRE-luciferase reporter construct then co-cultured with mouse MФs in the presence of LPS. A significant increase in PPAR $\gamma$ transcriptional activity was observed $48 \mathrm{~h}$ after LPS stimulation (fig. $5 \mathrm{a}$ ). Such an increase in PPAR $\gamma$ activation was not observed without co-culturing with MФs (fig. 5b). Moreover, MФ TLR4 signaling was responsible for the induction of PPAR $\gamma$ activation in IECs in response to LPS because LPS stimulation failed to activate PPAR $\gamma$ in IECs when we used TLR4-deficient $\mathrm{M} \Phi$ s (fig. 5c). Consistently, immunofluorescent detection of cellular localization of PPAR $\gamma$ demonstrated nuclear accumulation of PPAR $\gamma 48 \mathrm{~h}$ after LPS stimulation (fig. 5d).

These results suggest that LPS stimulation of IEC-MФ co-culture leads to accumulation and activation of PPAR $\gamma$ in IECs by inhibiting proteasomal degradation of PPAR $\gamma$ in IECs and 15d-PGJ2 synthesis by MФs, respectively.

\section{IL-10 Promoter Isolated from Human IECs Has PPRE Motifs}

We examined whether the activated PPAR $\gamma$ directly induces IL-10 expression in IECs by cloning the hIL-10
Hyun et al. 

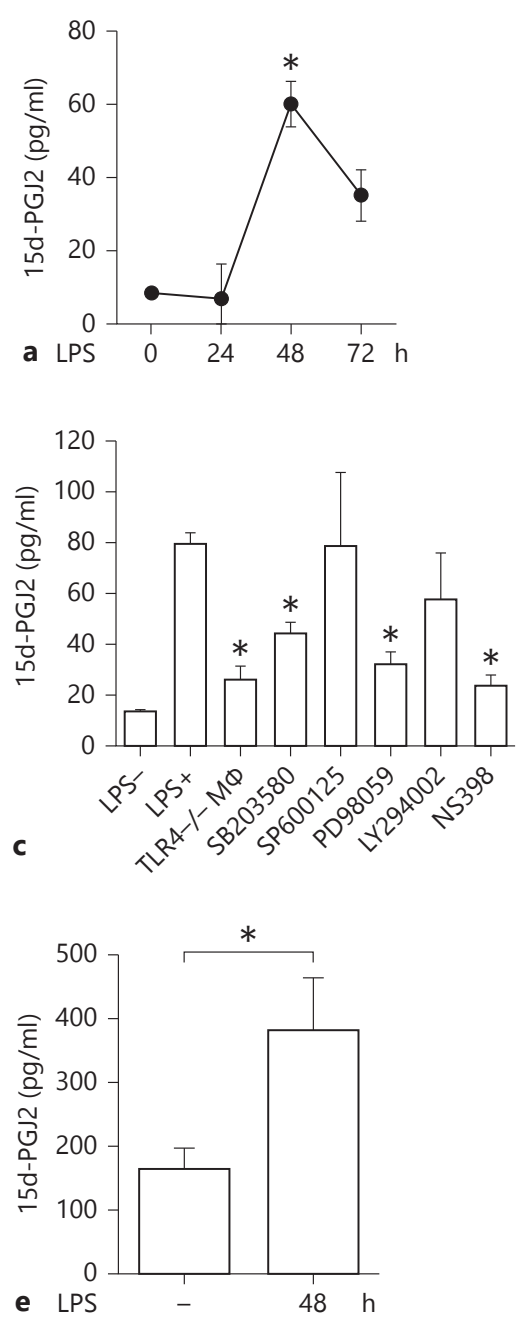
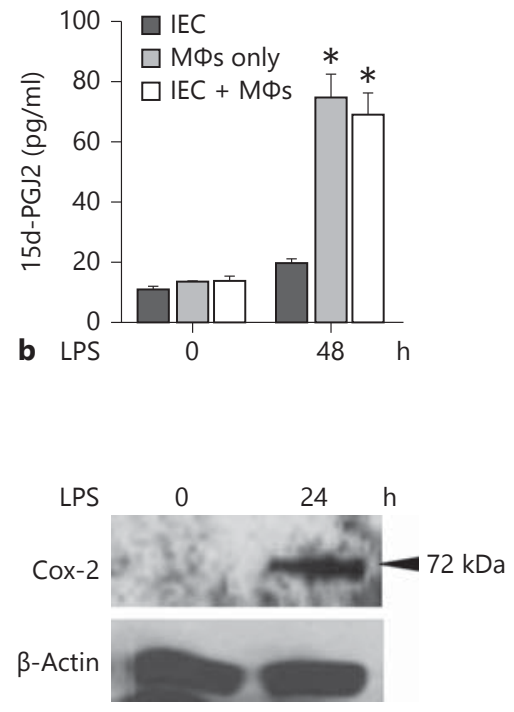

d

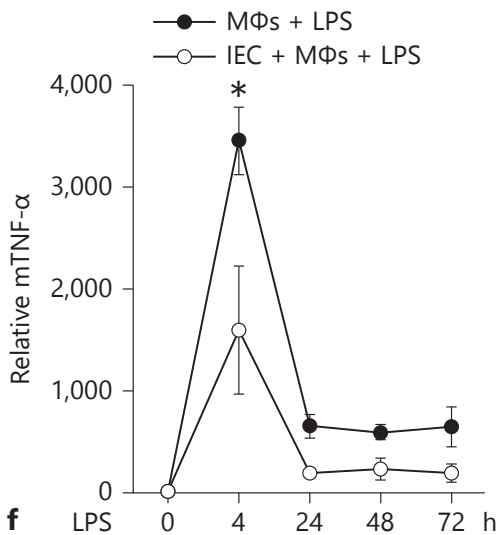

Fig. 3. LPS stimulates MФ 15d-PGJ2 synthesis through TLR4-dependent activation of $\mathrm{p} 38$, ERK MAP kinases and Cox-2 induction during co-culturing with IECs. a 15d-PGJ2 synthesis in IEC-MФ co-culture. Polarized SW480-APC cells were co-cultured with mouse peritoneal MФs in the Transwell system. LPS was added to the bottom wells. Supernatant from the bottom wells was measured for 15d-PGJ2 by EIA at the indicated periods. Data from three independent experiments of duplicate samples with SEM $\left({ }^{*} \mathrm{p}<0.05\right)$. b $15 \mathrm{~d}-\mathrm{PGJ} 2$ synthesis by cell types. Mouse peritoneal MФs were co-cultured with or without polarized SW480-APC cells (IECs) in the Transwell system. LPS was added to the wells of MФs. Polarized IECs without MФs were basolaterally stimulated with LPS as indicated. Supernatant from the bottom wells was measured for 15d-PGJ2 at the indicated periods. Data from three independent experiments of duplicate samples with SEM $(* \mathrm{p}<$ 0.05). c 15d-PGJ2 synthesis during inhibition of Cox-2 or PI3 and MAP kinases. Polarized SW480-APC cells were co-cultured with mouse peritoneal MФs in the Transwell system. To block TLR4 signaling, some wells were prepared with MФs from TLR4-/mice. Inhibitors for p38 (SB203580; $20 \mu \mathrm{M})$, JNK (SP600125; 20 $\mu \mathrm{M})$, ERK (PD98059; $20 \mu \mathrm{M})$, PI3K (LY294002; $20 \mu \mathrm{M})$ and Cox-2
(NS398; $5 \mu \mathrm{M}$ ) were added to the bottom wells. Ninety minutes later, LPS was added to the bottom wells. Supernatant from the bottom wells was measured for 15d-PGJ2 after $48 \mathrm{~h}$. Data from two independent experiments of triplicate samples with SEM $(* \mathrm{p}<$ 0.05). d Western blot analysis of Cox-2 in MФs. Mouse peritoneal MФs were co-cultured with SW480-APC cells in the Transwell system. Protein samples were harvested from MФs before and after $24 \mathrm{~h}$ of LPS stimulation in the bottom wells. An equal amount of protein was loaded per lane. The membrane was sequentially probed for Cox- 2 and $\beta$-actin. Representative results from three repeated experiments are shown. e 15d-PGJ2 synthesis in human colonic MФs. Freshly isolated lamina propria MФs (CD64 \pm cells) were stimulated with LPS for 48 h. 15d-PGJ2 concentrations in supernatants were measured by EIA. Data of triplicate samples from 2 human subjects with SEM $(* \mathrm{p}<0.05)$. f Real-time PCR results of TNF- $\alpha$ mRNA expression (mTNF- $\alpha$ ) in mouse peritoneal MФs with or without co-culturing with IECs in the Transwells. The relative expression of mouse TNF- $\alpha$ to $\beta$-actin after LPS stimulation is shown. Data from three independent experiments of triplicated samples with SEM $(* \mathrm{p}<0.05)$. 
Fig. 4. Epithelial TLR4 signaling inhibits degradation of PPAR $\gamma$ protein. a Western blot analysis of PPAR $\gamma$ in SW480-APC cells. SW480-APC cells were stimulated with LPS in conventional wells for the indicated periods. An equal amount of protein was loaded per lane. The membrane was sequentially probed for PPAR $\gamma$ and $\beta$-actin. Representative results from three repeated experiments are shown. b Real-time PCR results in PPAR $\gamma$ mRNA expression in SW480-APC cells grown in conventional wells. Cells were stimulated with LPS for the indicated period. The relative expression of human PPAR $\gamma$ to $\beta$-actin is shown. Data from three independent experiments of triplicate samples with SEM. n.s. = Nonsignificant. c Detection of ubiquitinated PPAR $\gamma$ by immunoprecipitation. Polarized SW480-APC cells were co-cultured with mouse peritoneal M $\Phi$ s and basolaterally stimulated with LPS for the indicated periods. $400 \mu \mathrm{g}$ of protein from SW480APC cell lysates were immunoprecipitated with anti-PPAR $\gamma$ or control IgG and immunoblotted with HRP-conjugated antiUb monoclonal antibody (P4D1), followed by anti-PPAR $\gamma$ (bottom). Representative results from three repeated experiments are shown. Graph shows quantitative Ub band (each molecular weight level) intensity normalized with PPAR $\gamma$ band measured with ImageJ.
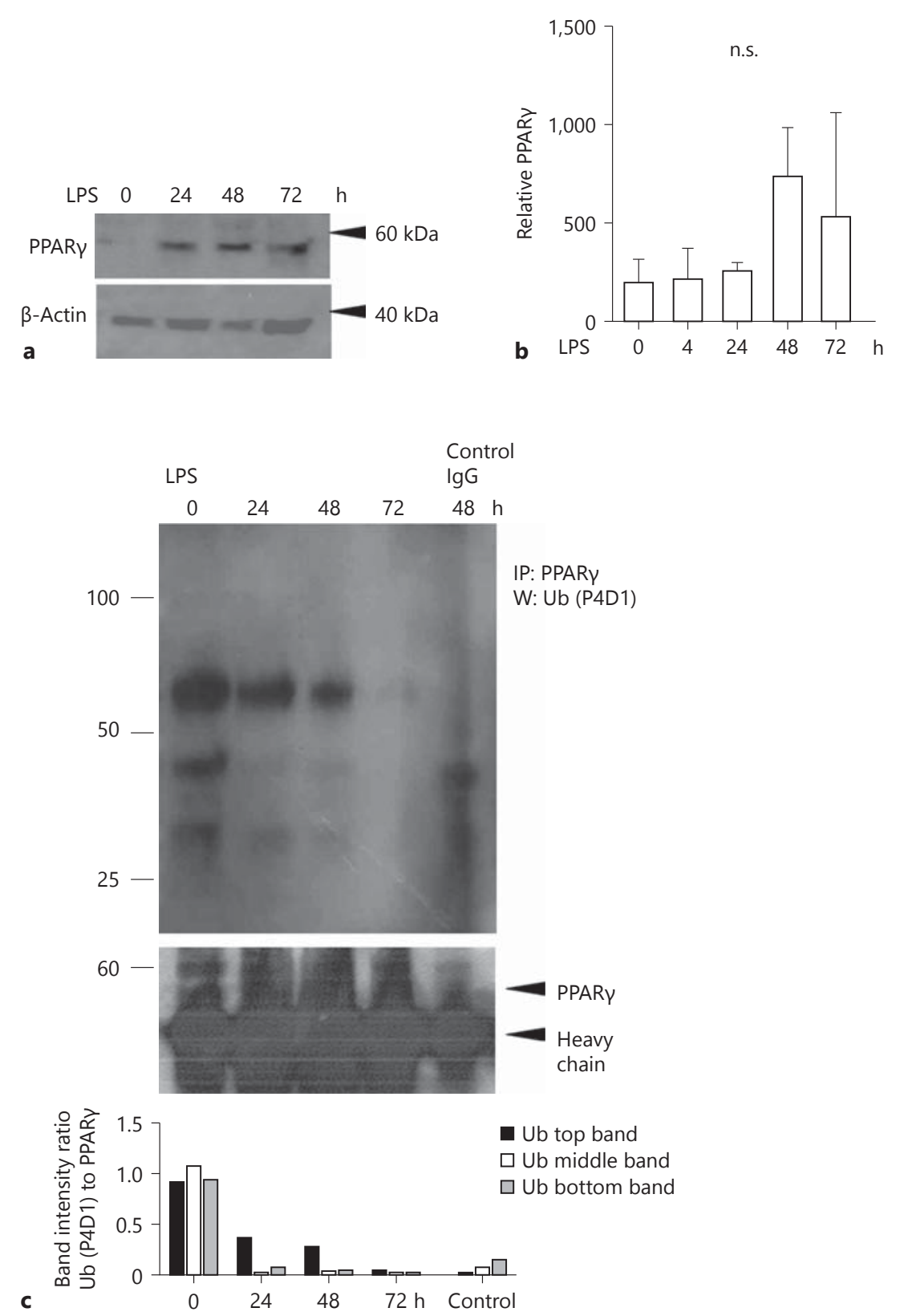

promoter in SW480-APC genomic DNA. PPAR $\gamma$ binds as heterodimer with members of the retinoid $\mathrm{X}$ receptor family to PPREs that are composed of a direct repeat of two half sites of the consensus sequences [32]. Based on previous reports, we found two possible PPRE motifs in the hIL-10 promoter (406-394 and 521-509 bp upstream from the ATG start codon; fig. 6a). To confirm the PPAR $\gamma$ binding sites within the hIL-10 promoter, we generated four luciferase reporter constructs serially truncated at the $5^{\prime}$ end of the IL-10 promoter. These reporter constructs were transfected to SW480-APC cells and examined for IL-10 promoter activities in response to LPS stimulation during co-culturing with MФs. All the constructs that carried a PPRE motif in the 406- to 394-bp upstream region showed significant IL-10 promoter activity (fig. 6b). The construct truncated at the region from -521 to $-509(-500)$ still showed IL-10 promoter activity in response to LPS but the truncation deleted at the region 


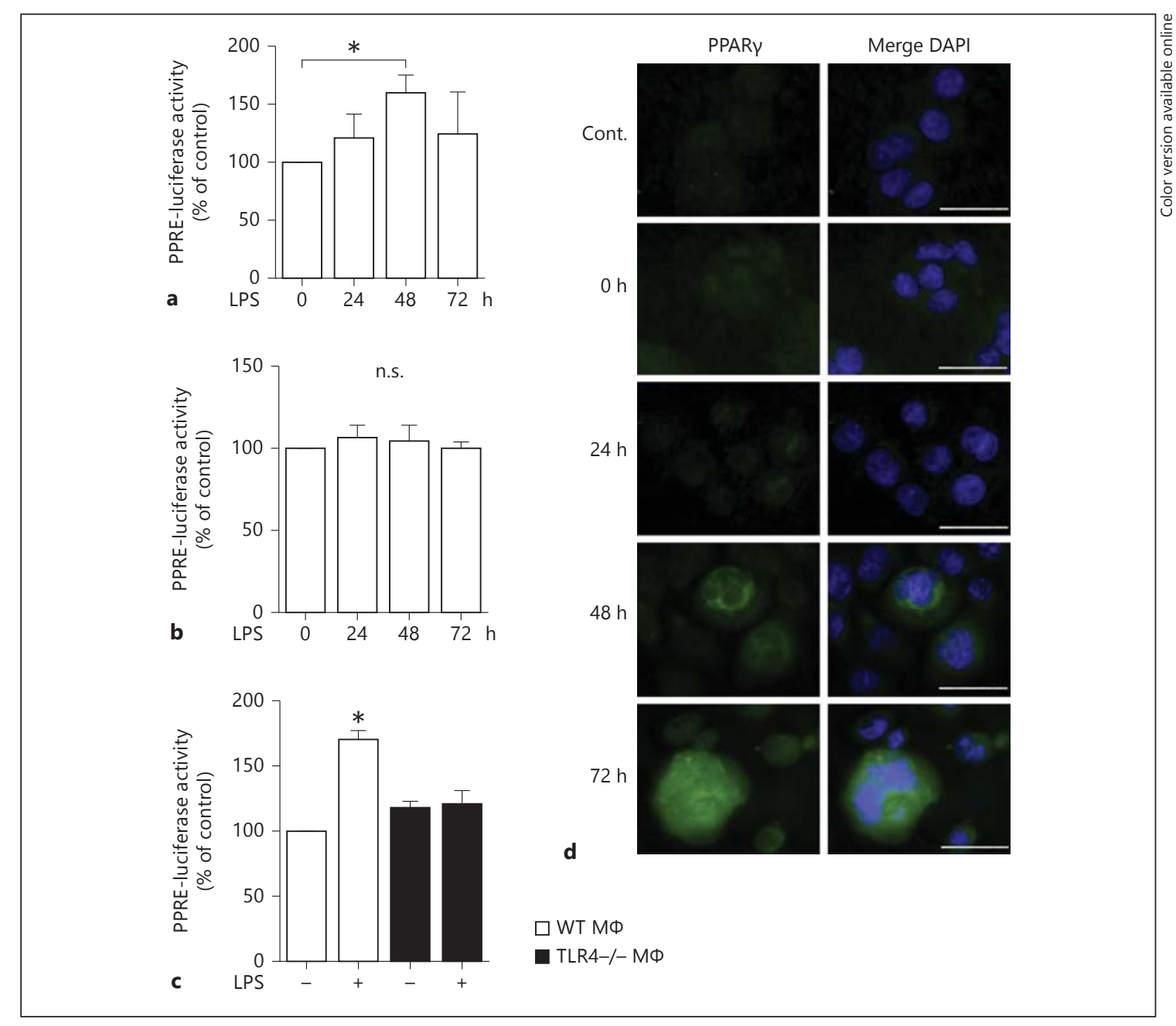

Fig. 5. MФ TLR4 signaling induces activation of PPAR $\gamma$ in IECs during IEC-MФ co-culture. a PPAR $\gamma$ activation in SW480-APC cells during co-culturing with MФs. SW480-APC cells were transfected with a PPRE-luciferase reporter construct and co-cultured with MФs in the Transwell system. LPS was added to the bottom wells for the indicated periods. PPAR $\gamma$ activation was expressed as percent increase of PPRE-luciferase activity over control (no LPS). Data from three independent experiments of duplicate samples with SEM $(* \mathrm{p}<0.05)$. b PPAR $\gamma$ activation in SW480-APC cells without MФ co-culture. SW480-APC cells were transfected with a PPRE-luciferase reporter construct and plated in the Transwell insert. Cells were basolaterally stimulated with LPS as indicated. PPAR $\gamma$ activation was expressed as percent increase of PPRE-luciferase activity over control (no LPS). Data from three independent experiments of duplicate samples with SEM. n.s. = Nonsig-

from -406 to -394 abolished the LPS-mediated IL-10 promoter activity (fig. 6b). Therefore, PPRE in the region from -406 to -394 of the IL-10 promoter is responsible for PPAR $\gamma$-dependent IL-10 promoter activity. Direct stimulation of SW480-APC cells carrying full-length IL- nificant. c Involvement of MФ TLR4 signaling in PPAR $\gamma$ activation of SW480-APC cells. SW480-APC cells were transfected with a PPRE-luciferase reporter construct and co-cultured with mouse peritoneal MФs isolated from TLR4-/- mice or WT littermates in the Transwell system. LPS was added to the bottom wells. PPAR $\gamma$ activation was measured after $48 \mathrm{~h}$ as percent increase in PPREluciferase activity over control (no LPS). Data from three independent experiments of duplicate samples with SEM $\left({ }^{*} p<0.05\right)$. d Immunofluorescent detection of cellular localization of PPAR $\gamma$. Polarized SW480-APC cells were co-cultured with mouse peritoneal MФs in the Transwell system and basolaterally stimulated with LPS for the indicated periods. PPAR $\gamma$ was labeled with Alexa Fluor 488 (green in the online version). Nuclei were stained with DAPI (blue in the online version). Original magnification $\times 40$. Bars: $50 \mu \mathrm{m}$.

10 promoter with $15 \mathrm{~d}-\mathrm{PGJ} 2(5 \mathrm{ng} / \mathrm{ml}$ for $48 \mathrm{~h})$ in the absence of LPS did not show increased luciferase activity (data not shown), suggesting the requirement of TLR4mediated PPAR $\gamma$ expression for transcriptional activity of IL-10 in IECs. 


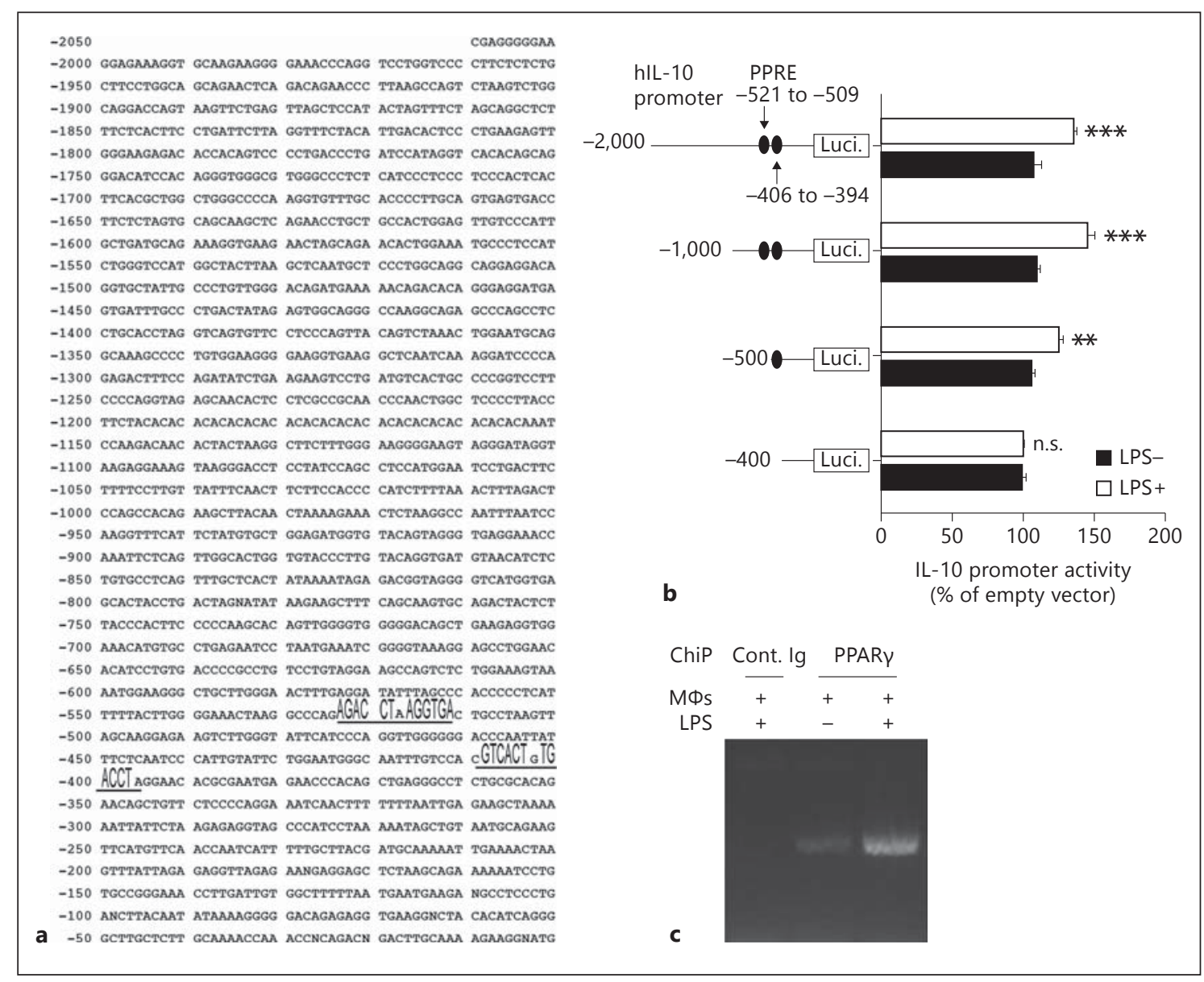

Fig. 6. Detection of functional PPRE motif in IL-10 promoter in human IEC. a hIL-10 promoter sequence in genomic DNA isolated from SW480-APC cells. PPRE motifs are underlined. b Detection of a functional PPRE element in hIL-10 promoter. SW480APC cells were transfected with truncated hIL-10 promoter fragments of various lengths and co-cultured with mouse peritoneal MФs in the Transwell system. LPS was added to the bottom wells and IL-10 promoter activity was measured after $72 \mathrm{~h}$ as percent increase of luciferase activity over control (empty vector). Data

To further confirm the direct binding of PPAR $\gamma$ to the region from -406 to -394 of the IL-10 promoter, we performed a ChIP assay. Nuclear protein was immunoprecipitated with PPAR $\gamma$ and PCR amplified using a primer set that was used to clone the -500 -bp hIL-10 promoter construct. We detected this region of hIL-10 promoter in the DNA fragment that bound with PPAR $\gamma$ in LPS-stimulated SW480-APC cells (fig. 6c). These results indicate that activated PPAR $\gamma$ in SW480-APC cells directly binds to the PPRE motif in the IL-10 promoter, which is induced by LPS stimulation during co-culturing of SW480APC cells with MФs. from three independent experiments of duplicate samples with $\operatorname{SEM}\left({ }^{* *} \mathrm{p}<0.01,{ }^{* * *} \mathrm{p}<0.001\right)$. n.s. $=$ Nonsignificant. $\mathrm{c}$ The binding of PPAR $\gamma$ to hIL-10 promoter. Polarized SW480-APC cells were co-cultured with mouse peritoneal MФs in the Transwell system and basolaterally stimulated with LPS for $72 \mathrm{~h}$ as indicated. Nuclear protein was isolated from LPS-stimulated and non-stimulated SW480-APC cells and subjected to ChiP assay. Normal rabbit IgG was used for immunoprecipitation of control samples. Representative results from three repeated experiments are shown.

\section{MФ TLR4-Mediated Late Induction of IL-10 in IECs Is PPAR $\gamma$ Dependent}

Next, we addressed whether the observed IL-10 promoter activity is PPAR $\gamma$ specific and the PPAR $\gamma$ binding to IL-10 promoter results in IL-10 expression in SW480APC cells during co-culturing with MФs. Blocking PPAR $\gamma$ by the PPAR $\gamma$ antagonist SR202 abolished LPSmediated IL-10 promoter activity and the late induction of IL-10 mRNA in our SW480-APC MФ co-culture system (fig. 7a, b). This effect of SR202 on IL-10 expression was not observed without MФs, confirming that the activation of PPAR $\gamma$ in SW480-APC cells requires a MФ re- 


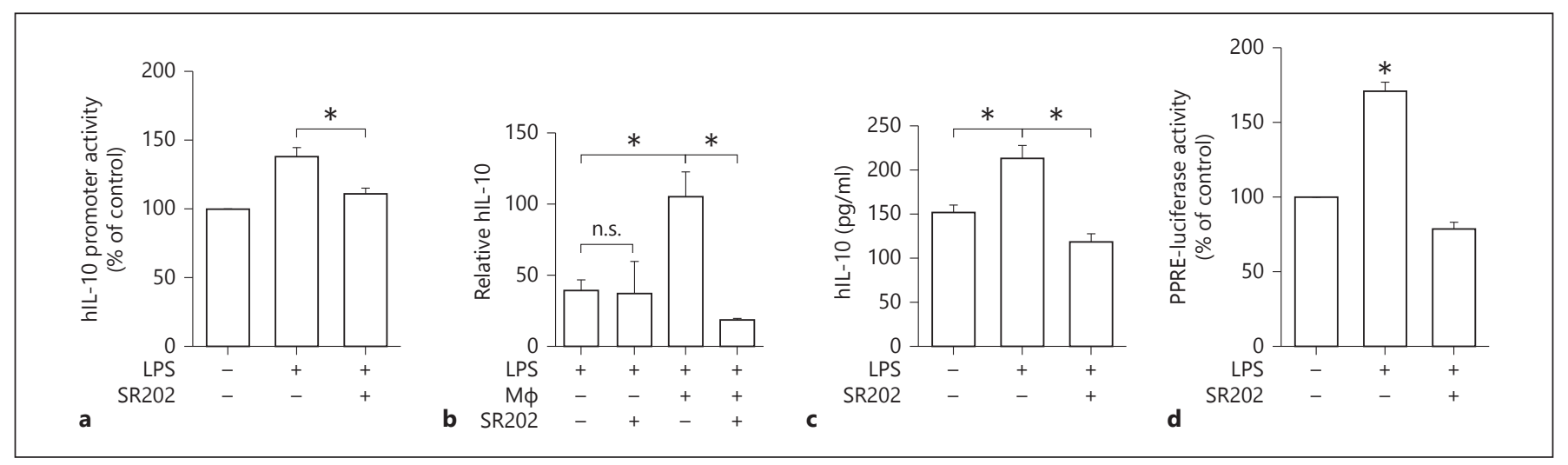

Fig. 7. The late induction of IL-10 in IEC-MФ co-culture is epithelial PPAR $\gamma$ dependent. a IL-10 promoter activity. SW480-APC cells were transfected with -2,000-bp hIL-10 promoter and co-cultured with mouse peritoneal MФs in the Transwell system. LPS was added to the bottom wells and IL-10 promoter activity was measured after $72 \mathrm{~h}$ as percent increase in luciferase activity over control (no LPS). The PPAR $\gamma$ antagonist SR202 $(500 \mu \mathrm{M})$ was added to insert wells 90 min prior to LPS stimulation. Data from two independent experiments of duplicate samples with SEM $(* \mathrm{p}<0.05)$. b Real-time PCR results of IL-10 mRNA expression in polarized SW480-APC cells in the presence or absence of PPAR $\gamma$ antagonist. Polarized SW480APC cells with or without mouse peritoneal MФs were basolaterally stimulated with LPS for $72 \mathrm{~h}$. PPAR $\gamma$ antagonist SR202 $(500 \mu \mathrm{M})$ was added to insert wells 90 min prior to LPS stimulation. The relative expression of hIL-10 to $\beta$-actin is shown. Data from three independent experiments of triplicate samples with SEM $(* p<0.05)$. n.s. $=$

sponse to LPS (fig. 7b). Corresponding IL-10 protein production by SW480-APC cells was also abrogated by SR202 (fig. 7c). Furthermore, the IL-10 expression pattern was comparable to the PPAR $\gamma$ transcriptional activity determined by PPRE-luciferase assay (fig. 7d). These results indicate that the late IL-10 expression by SW480-APC cells depends on PPAR $\gamma$ activation in SW480-APC cells, which requires MФ TLR4 signaling.

\section{Epithelial-MФ Crosstalk Induces IL-10 Expression in IECs via MФ Cox-2 Induction and Epithelial PPARy Activation}

In order to map the cellular pathway in epithelial-M $\Phi$ crosstalk that evokes epithelial IL-10 expression in response to LPS, we utilized another human IEC line (Caco2) that is known to be hyporesponsive to LPS and constitutively expresses PPAR $\gamma$ (fig. 8a). Using Caco-2 cells allowed us to investigate IEC-M $\Phi$ crosstalk without the effect of IECs on MФs that were induced by LPS stimulation. Caco-2 cells were polarized in the Transwell inserts and co-cultured with peritoneal MФs that were seeded in the bottom wells. Consistent with SW480-APC cells,
Nonsignificant. c The effect of SR202 on IL-10 production from polarized SW480-APC cell co-culturing with mouse peritoneal MФs in the Transwell system. Cells were basolaterally stimulated with LPS for $72 \mathrm{~h}$ as indicated. PPAR $\gamma$ antagonist SR202 $(500 \mu \mathrm{M})$ was added to insert wells 90 min prior to LPS stimulation. hIL-10 protein concentration in the bottom wells was measured by specific ELISA. Data from three independent experiments of duplicate samples with SEM $\left({ }^{*} \mathrm{p}<0.05\right)$. $\mathbf{d}$ The effect of SR202 on PPAR $\gamma$ activation in SW480APC cells during co-culturing with MФs. SW480-APC cells were transfected with a PPRE-luciferase reporter construct and co-cultured with mouse peritoneal MФs in the Transwell system. LPS was added to the bottom wells for $48 \mathrm{~h}$ as indicated. The PPAR $\gamma$ antagonist SR202 $(500 \mu \mathrm{M})$ was added to insert wells 90 min prior to LPS stimulation. PPAR $\gamma$ activation was expressed as percent increase in PPRE-luciferase activity over control (no LPS). Data from three independent experiments of duplicate samples with SEM $\left({ }^{*} \mathrm{p}<0.05\right)$.

Caco- 2 cells induced IL-10 expression $72 \mathrm{~h}$ after adding LPS in the bottom wells, but early induction of IL-10 in 24-hour LPS stimulation was not observed (fig. 8b). Corresponding IL-10 protein expression was confirmed by ELISA, which was not observed without MФs (fig. 8c). In this system, knocking down PPAR $\gamma$ completely abolished LPS-mediated IL-10 transcriptional activity determined by IL-10 promoter luciferase assay (fig. $8 \mathrm{~d}$ ). 15d-PGJ2 stimulation induced IL-10 promoter activity in Caco-2 cells, which was not seen in SW480-APC cells, confirming the requirement of PPAR $\gamma$ in 15d-PGJ2-mediated IL10 expression in human IECs. The IL-10 transcriptional activity reflected IL-10 protein expression in Caco- 2 cells (fig. 8e). Although PPAR $\gamma$ is constitutively expressed in Caco-2 cells, its transcriptional activity is induced by TLR4-mediated Cox-2 induction in MФs as the presence of Cox-2 inhibitor (NS398) completely abolished LPS-induced PPRE activity in Caco- 2 cells during co-culturing with MФs (fig. 8f). These results suggest that IL-10 expression from human IECs is PPAR $\gamma$ dependent and inducible by activation of adjacent MФs through TLR4-mediated Cox-2 induction. 


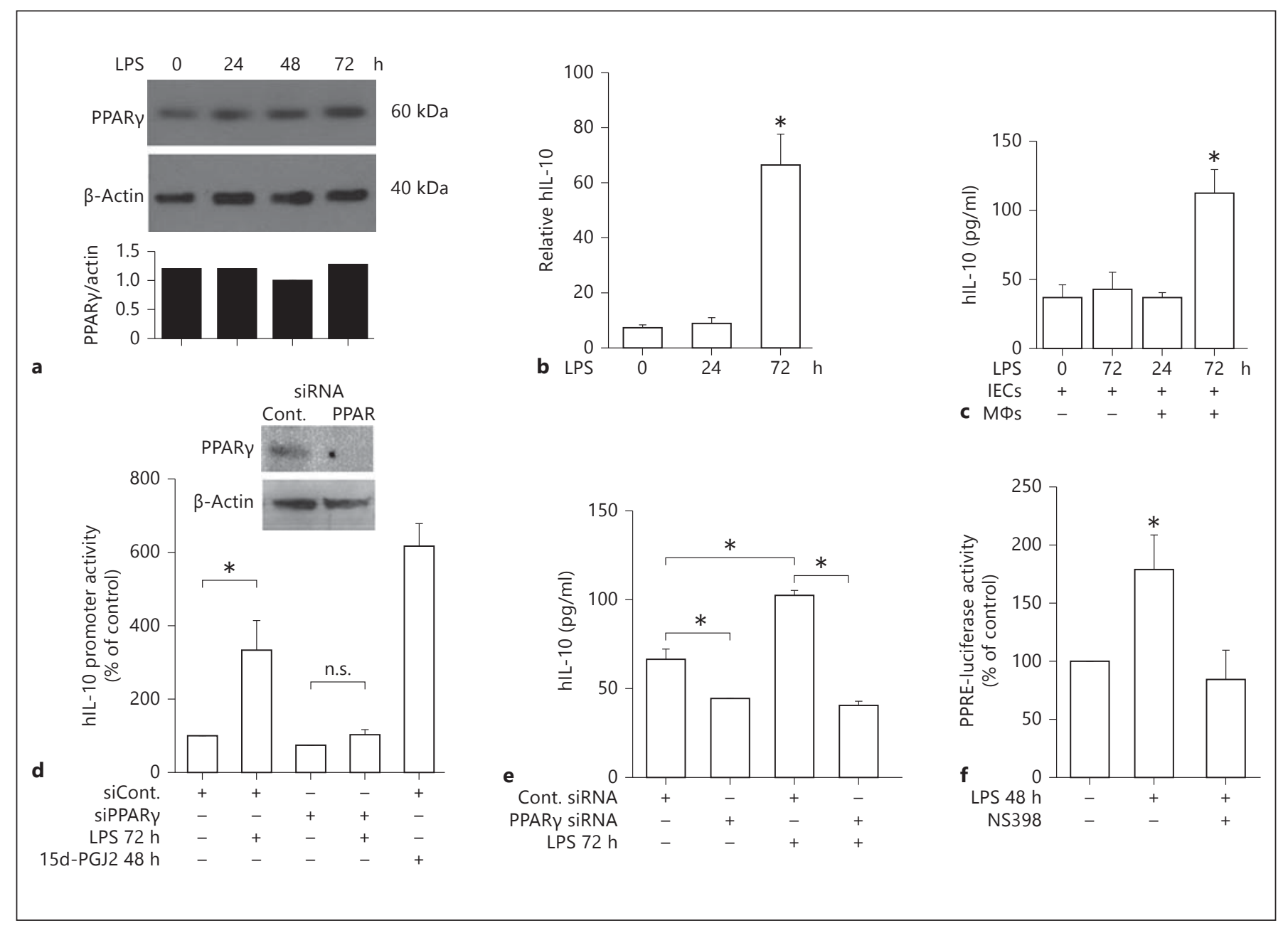

Fig. 8. The role of epithelial PPAR $\gamma$ activation in IL-10 expression by IECs that are induced by MФ TLR4 signaling. a Western blot analysis of PPAR $\gamma$ in Caco-2 cells. Caco-2 cells were stimulated with LPS in conventional wells for the indicated periods. An equal amount of protein was loaded per lane. The membrane was sequentially probed for PPAR $\gamma$ and $\beta$-actin. Representative results from three repeated experiments are shown. Graph shows ratios of PPAR $\gamma$ band intensity normalized with $\beta$-actin band measured with ImageJ. b Real-time PCR results of IL-10 mRNA expression in polarized Caco- 2 cells. Polarized Caco- 2 cells were co-cultured with mouse peritoneal MФs in the Transwell system and basolaterally stimulated with LPS for the indicated periods. The relative expression of hIL-10 to $\beta$-actin is shown. Data from three independent experiments of triplicate samples with SEM $\left({ }^{*} \mathrm{p}<0.05\right)$. c IL10 production from polarized Caco- 2 cells with or without co-culturing with mouse peritoneal MФs in the Transwell system. Cells were basolaterally stimulated with LPS for the indicated periods. hIL-10 protein concentration in the bottom wells was measured by specific ELISA. Data from three independent experiments of duplicate samples with SEM $(* \mathrm{p}<0.05)$. d The role of PPAR $\gamma$ in the transcriptional activity of IL-10 in human IECs. Caco- 2 cells were transfected with hIL-10 promoter construct together with siRNA against PPAR $\gamma$ and co-cultured with mouse peritoneal MФs in the Transwell system. Control cells received IL-10 promoter construct and nonspecific siRNA. LPS was added to the bottom wells and IL-10 promoter activity was measured after $72 \mathrm{~h}$ as percent increase in luciferase activity over control (no LPS, control siRNA). The extent of PPAR $\gamma$ knockdown was assessed by Western blot. $15 \mathrm{~d}-\mathrm{PGJ} 2(5 \mathrm{ng} / \mathrm{ml})$ was used as a positive control. Data from three independent experiments of duplicate samples with SEM $(* p<$ 0.05). n.s. $=$ Nonsignificant. e IL-10 production from polarized Caco- 2 cells knocking down PPAR $\gamma$. Caco- 2 cells were transfected with siRNA against PPAR $\gamma$ and co-cultured with mouse peritoneal MФs in the Transwell system. Control cells were transfected with nonspecific siRNA. Cells were basolaterally stimulated with LPS for $72 \mathrm{~h}$ as indicated. hIL-10 concentration in the bottom wells was measured by specific ELISA. Data from three independent experiments of duplicate samples with SEM $\left({ }^{*} \mathrm{p}<0.05\right)$. f The effect of $\mathrm{M} \Phi$ Cox-2 induction on PPAR $\gamma$ activation in Caco- 2 cells during co-culturing with MФs. Caco-2 cells were transfected with a PPRE-luciferase reporter construct and co-cultured with mouse peritoneal MФs in the Transwell system. LPS was added to the bottom wells for $48 \mathrm{~h}$ as indicated. Cox-2 antagonist NS398 (5 $\mu \mathrm{M})$ was added to the bottom wells 90 min prior to LPS stimulation. PPAR $\gamma$ activation was expressed as percent increase in PPRE-luciferase activity over control (no LPS). Data from three independent experiments of duplicate samples with SEM $(* \mathrm{p}<0.05)$. 


\section{Discussion}

Intestinal mucosal immune responses to luminal commensal microorganisms are regulated by active immunomodulation in which the expression of anti-inflammatory cytokines from IECs maintains a controlled state of inflammation. While the importance of epithelial IL-10 expression in keeping epithelial integrity has been described in the intestine, the precise mechanism regulating epithelial IL-10 expression in the context of facing numerous commensal microorganisms has remained elusive. In this study, we show an important role of TLR4mediated crosstalk between IECs and MФs in epithelial expression of IL-10. The underlying mechanism of epithelial IL-10 production involves activation of the nuclear receptor PPAR $\gamma$ in IECs. On the other hand, TLR4 signaling in MФs induces 15d-PGJ2 synthesis via Cox-2 expression that is required for PPAR $\gamma$ activation in adjacent IECs. These results outline a sequential molecular and cellular pathway by which TLR4 signaling coordinates intestinal immunomodulation in response to commensal bacteria.

In normal intestinal mucosa, $\mathrm{M} \Phi$ s are located underneath the epithelial lining [33]. It has been reported that these subepithelial MФs crosstalk with adjacent IECs through TLR-dependent Cox-2 expression $[15,16]$. While intestinal $M \Phi$ s isolated from human jejunum are known to be unresponsive to LPS mainly due to lack of CD14 expression, CD14-expressing MФs are identified in normal human colonic mucosa [34]. Their response to LPS seems to be regulated by retinaldehyde dehydrogenase activity, and abnormal responses of this $М \Phi$ population to commensal bacteria has been implicated in the pathogenesis of human IBD [34-36]. How these potentially LPS-responsive lamina propria MФs are regulated in normal colonic mucosa is obscure, but induction of immunomodulatory $15 \mathrm{~d}-\mathrm{PGJ} 2$ may contribute to the regulation of inflammatory responses of LPS-activated MФs to keep mucosal homeostasis in the normal colon. Since Cox-2 is known to induce prostaglandin synthesis, we examined whether MФs produced 15d-PGJ2 in response to TLR4 activation. We confirmed a significant induction of Cox-2 followed by 15d-PGJ2 synthesis in LPS-stimulated MФs that is mediated through p38 and ERK1/2 MAP kinases. We also confirmed induction of $15 \mathrm{~d}-\mathrm{PG} 2$ in primary colonic MФs (CD64 \pm cells) in response to LPS. It is likely that MФs are the major source of $15 \mathrm{~d}-\mathrm{PGJ} 2$ in the intestine because Cox-2 expression is mainly observed in lamina propria $М \Phi s$ [29], and the amount of 15d-PGJ2 produced is similar in the presence and absence of IECs in our co-culture system. In addition, IECs increased intracellular PPAR $\gamma$ protein in response to LPS. This corresponded to the significant reduction in ubiquitination of PPAR $\gamma$ protein. The Ub-dependent proteasome pathway is known to regulate several transcription factors, including PPAR $\gamma$ [37]. The Ub-dependent degradation of PPAR $\gamma$ not only regulates intracellular protein levels but also directly influences PPAR $\gamma$ activation as the ubiquitination occurs in the ligand-binding domain of PPAR $\gamma$ [38]. Furthermore, 15d-PGJ2 has been shown to inhibit the Ub-dependent proteasome pathway in IECs [39].

Although LPS stimulation has shown to induce PPAR $\gamma$ mRNA expression in Caco-2 cells, neither SW480-APC cells nor Caco-2 cells showed a significant difference in PPAR $\gamma$ mRNA before and after LPS stimulation in our system [22]. This discrepancy may be due to differences in transcriptional responses of each PPAR $\gamma$ mRNA isoform in that IECs express multiple PPAR $\gamma$ mRNA isoforms that use different promoters [40]. Since each PPAR $\gamma$ mRNA isoform has different sequences in the $\mathrm{N}$ terminal region, different primer sets detect distinct isoforms of PPAR $\gamma$ mRNA. In our study, we used a primer set that can detect the universal region of PPAR $\gamma$ mRNA. Functionally, the existence of MФs was required for PPAR $\gamma$ activation in IECs because we could not see LPSinduced PPAR $\gamma$ activation and nuclear accumulation in IECs when they were not co-cultured with MФs. Overall, our results indicate that TLR4-mediated IEC-M $\Phi$ crosstalk triggers epithelial PPAR $\gamma$ activation through Cox-2 induction and 15d-PGJ2 production from MФs.

Animal studies have demonstrated the importance of IL-10 in the maintenance of host immune responses to intestinal commensal bacteria [6, 7]. A recent report has also shown that conditional deletion of epithelial-specific IL-10 in mice results in increased susceptibility to oxazolone-induced colitis [41]. However, the role of IECs as a source of IL-10 differs between mice and humans because mouse IECs do not constitutively express IL-10 without stimulation [10]. In human IECs, we confirmed the expression of IL-10 mRNA in isolated normal colonic epithelial cells from surgically resected specimens. It has been shown that the expression of IL-10 maintains epithelial integrity by suppressing the expression of detrimental proinflammatory cytokines and apoptotic cell death $[9,42]$. These findings imply unique regulation of IL-10 expression in human IECs. In general, gene expression is tightly regulated by binding of a group of transcription factors to specific promoter regions of the gene, which differs among cell types [43]. Several transcription 
factors, such as Sp1, Sp3, NF-Y, STAT3 and C/EBP, are known to bind to the hIL-10 promoter in monocytes and $\mathrm{M} \Phi$ s [44-46]. Contribution of PPAR $\gamma$ in the transcriptional regulation of human M $\Phi$ IL-10 promoter activity has also been shown [47]. However, little is known about transcriptional regulation of IL-10 in human IECs. We found in this study that LPS stimulation induces two phases of IL-10 expression by IECs during co-culturing with $M \Phi s$. The first phase could be seen without $M \Phi s$ and was prior to the nuclear accumulation of PPAR $\gamma$ in IECs, indicating that the first phase of IL-10 expression is independent of PPAR $\gamma$, while the second phase was PPAR $\gamma$ dependent and required Cox-2 induction in MФs. Although it is still unclear whether these two phases of IL-10 expression have distinct roles in the maintenance of host immune responses to intestinal bacteria, PPAR $\gamma$ activation via TLR4-mediated epithelial-M $\Phi$ crosstalk may be important to keep a biologically active level of IL-10 in the intestinal mucosa since the level of IL-10 induction is greater in the second rather than the first phase. Based on these findings, we propose an immunological model in which TLR4-mediated crosstalk between IECs and MФs maintains mucosal integrity in the human colon. Upon minor mucosal injury of the colon, innate proinflammatory responses may be initiated rapidly, while sequential induction of innate anti-inflammatory responses composed of 15d-PGJ2 and the late induction of epithelial IL10 gives enough time to prepare a host-defense program against possible invasion of luminal microorganisms by regulating inflammatory overdrive until more precise adaptive immunity is mobilized.
Unlike other organs in our body, the gastrointestinal tract houses countless bacteria. In order to keep this unique nature of the gut, active and sustained immunoregulation is crucial to dampen intestinal inflammatory signaling in response to commensal bacteria. We demonstrated in this study that TLR4-induced IEC-M $\Phi$ crosstalk leads to the activation of PPAR $\gamma$ and IL-10 production in IECs. Given the importance of IL-10 in the maintenance of our intestinal homeostasis, it is interesting that this IEC-MФ crosstalk relies on commensal bacteria. Many disease conditions in the gastrointestinal tract have been expected to involve the host-bacterial interactions. While IECs are normally hyporesponsive to apical bacterial stimuli, epithelial leakage may occur upon a variety of physiological conditions leading to initiation of host response to microbial products, which has been implicated as a predisposing factor of irritable bowel disease and IBD [4, 5, 48, 49]. Our results outline the physiological mechanism of intestinal host-microbial interactions, which may provide cues to understand the pathogenesis of gastrointestinal diseases that involve abnormal host response to commensal bacteria.

\section{Acknowledgments}

This study was supported by a Senior Research Award from the Crohn's Colitis Foundation of America (3391) to M.F.

\section{Disclosure Statement}

The authors have no conflicting financial interests.

\section{References}

$\checkmark 1$ Fukata M, Arditi M: The role of pattern recognition receptors in intestinal inflammation. Mucosal Immunol 2013;6:451-463.

2 Abreu MT: Toll-like receptor signalling in the intestinal epithelium: how bacterial recognition shapes intestinal function. Nat Rev Immunol 2010;10:131-144.

3 Vamadevan AS, Fukata M, Arnold ET, Thomas LS, Hsu D, Abreu MT: Regulation of Toll-like receptor 4-associated MD-2 in intestinal epithelial cells: a comprehensive analysis. Innate Immun 2010;16:93-103.

4 Vanuytsel T, van Wanrooy S, Vanheel $\mathrm{H}$ Vanormelingen C, Verschueren S, Houben E, Salim Rasoel S, Toth J, Holvoet L, Farre R, Van Oudenhove L, Boeckxstaens G, Verbeke $\mathrm{K}$, Tack J: Psychological stress and corticotropin-releasing hormone increase intestinal permeability in humans by a mast cell-dependent mechanism. Gut 2014;63:1293-1299.
5 Odenwald MA, Turner JR: Intestinal permeability defects: is it time to treat? Clin Gastroenterol Hepatol 2013;11:1075-1083.

- 6 Kuhn R, Lohler J, Rennick D, Rajewsky K, Muller W: Interleukin-10-deficient mice develop chronic enterocolitis. Cell 1993;75:263-274.

7 Sellon RK, Tonkonogy S, Schultz M, Dieleman LA, Grenther W, Balish E, Rennick DM, Sartor RB: Resident enteric bacteria are necessary for development of spontaneous colitis and immune system activation in interleukin-10-deficient mice. Infect Immun 1998;66:5224-5231.

8 Liu JJ, Davis EM, Wine E, Lou Y, Rudzinski JK, Alipour M, Boulanger P, Thiesen AL, Sergi C, Fedorak RN, Muruve D, Madsen KL, Irvin RT: Epithelial cell extrusion leads to breaches in the intestinal epithelium. Inflamm Bowel Dis 2013;19:912-921.

-9 Jarry A, Bossard C, Bou-Hanna C, Masson D, Espaze E, Denis MG, Laboisse CL: Mucosal
IL-10 and TGF-beta play crucial roles in preventing LPS-driven, IFN-gamma-mediated epithelial damage in human colon explants. J Clin Invest 2008;118:1132-1142.

10 Kamanaka M, Kim ST, Wan YY, Sutterwala FS, Lara-Tejero M, Galan JE, Harhaj E, Flavell RA: Expression of interleukin-10 in intestinal lymphocytes detected by an interleukin-10 reporter knockin tiger mouse. Immunity 2006 ; 25:941-952.

$\checkmark 11$ Autschbach F, Braunstein J, Helmke B, Zuna I, Schurmann G, Niemir ZI, Wallich R, Otto HF, Meuer SC: In situ expression of interleukin-10 in noninflamed human gut and in inflammatory bowel disease. Am J Pathol 1998;153:121-130.

12 Cinova J, De Palma G, Stepankova R, Kofronova O, Kverka M, Sanz Y, Tuckova L: Role of intestinal bacteria in gliadin-induced changes in intestinal mucosa: study in germ-free rats. PLoS One 2011;6:e16169. 
13 Canali MM, Porporatto C, Aoki MP, Bianco ID, Correa SG: Signals elicited at the intestinal epithelium upon chitosan feeding contribute to immunomodulatory activity and biocompatibility of the polysaccharide. Vaccine 2010; 28:5718-5724.

14 Hernandez Y, Sotolongo J, Breglio K, Conduah D, Chen A, Xu R, Hsu D, Ungaro R, Hayes LA, Pastorini C, Abreu MT, Fukata M: The role of prostaglandin E2 (PGE 2) in tolllike receptor 4 (TLR4)-mediated colitis-associated neoplasia. BMC Gastroenterol 2010;10: 82.

15 Pull SL, Doherty JM, Mills JC, Gordon JI, Stappenbeck TS: Activated macrophages are an adaptive element of the colonic epithelial progenitor niche necessary for regenerative responses to injury. Proc Natl Acad Sci USA 2005; 102:99-104.

-16 Brown SL, Riehl TE, Walker MR, Geske MJ, Doherty JM, Stenson WF, Stappenbeck TS: Myd88-dependent positioning of Ptgs2-expressing stromal cells maintains colonic epithelial proliferation during injury. J Clin Invest 2007;117:258-269.

-17 Castrillo A, Diaz-Guerra MJ, Hortelano S, Martin-Sanz P, Bosca L: Inhibition of IkappaB kinase and IkappaB phosphorylation by 15-deoxy-delta(12,14)-prostaglandin $J(2)$ in activated murine macrophages. Mol Cell Biol 2000;20:1692-1698.

18 Jiang C, Ting AT, Seed B: PPAR-gamma agonists inhibit production of monocyte inflammatory cytokines. Nature 1998;391:82-86.

19 Ricote M, Li AC, Willson TM, Kelly CJ, Glass CK: The peroxisome proliferator-activated receptor-gamma is a negative regulator of macrophage activation. Nature 1998;391:7982.

20 Fajas L, Auboeuf D, Raspe E, Schoonjans K, Lefebvre AM, Saladin R, Najib J, Laville M, Fruchart JC, Deeb S, Vidal-Puig A, Flier J, Briggs MR, Staels B, Vidal H, Auwerx J: The organization, promoter analysis, and expression of the human PPARgamma gene. J Biol Chem 1997;272:18779-18789.

21 Are A, Aronsson L, Wang S, Greicius G, Lee YK, Gustafsson JA, Pettersson S, Arulampalam V: Enterococcus faecalis from newborn babies regulate endogenous PPARgamma activity and IL-10 levels in colonic epithelial cells. Proc Natl Acad Sci USA 2008;105:19431948.

-22 Dubuquoy L, Jansson EA, Deeb S, Rakotobe S, Karoui M, Colombel JF, Auwerx J, Pettersson S, Desreumaux P: Impaired expression of peroxisome proliferator-activated receptor gamma in ulcerative colitis. Gastroenterology 2003;124:1265-1276.

23 Eun CS, Han DS, Lee SH, Paik CH, Chung YW, Lee J, Hahm JS: Attenuation of colonic inflammation by PPARgamma in intestinal epithelial cells: effect on Toll-like receptor pathway. Dig Dis Sci 2006;51:693-697.

-24 Shen C, Landers CJ, Derkowski C, Elson CO, Targan SR: Enhanced CBir1-specific innate and adaptive immune responses in Crohn's disease. Inflamm Bowel Dis 2008;14:16411651.

25 Lorenzi T, Turi A, Lorenzi M, Paolinelli F, Mancioli F, La Sala L, Morroni M, Ciarmela P, Mantovani A, Tranquilli AL, Castellucci M, Marzioni D: Placental expression of CD100, CD72 and CD45 is dysregulated in human miscarriage. PLoS One 2012;7:e35232.

26 Fukata M, Chen A, Vamadevan AS, Cohen J, Breglio K, Krishnareddy S, Hsu D, Xu R, Harpaz N, Dannenberg AJ, Subbaramaiah K, Cooper HS, Itzkowitz SH, Abreu MT: Tolllike receptor-4 promotes the development of colitis-associated colorectal tumors. Gastroenterology 2007;133:1869-1881.

27 Faux MC, Ross JL, Meeker C, Johns T, Ji H, Simpson RJ, Layton MJ, Burgess AW: Restoration of full-length adenomatous polyposis coli (APC) protein in a colon cancer cell line enhances cell adhesion. J Cell Sci 2004;117: 427-439.

28 Salas PJ: Insoluble gamma-tubulin-containing structures are anchored to the apical network of intermediate filaments in polarized CACO-2 epithelial cells. J Cell Biol 1999;146: 645-658.

29 Fukata M, Chen A, Klepper A, Krishnareddy $S$, Vamadevan AS, Thomas LS, Xu R, Inoue $H$, Arditi M, Dannenberg AJ, Abreu MT: Cox-2 is regulated by Toll-like receptor-4 (TLR4) signaling: role in proliferation and apoptosis in the intestine. Gastroenterology 2006;131: 862-877.

30 Lord AM, North TE, Zon LI: Prostaglandin E2: making more of your marrow. Cell Cycle 2007;6:3054-3057.

31 Nosjean O, Boutin JA: Natural ligands of PPARgamma: are prostaglandin $\mathrm{J}(2)$ derivatives really playing the part? Cell Signal 2002; 14:573-583.

32 Chandra V, Huang P, Hamuro Y, Raghuram S, Wang Y, Burris TP, Rastinejad F: Structure of the intact PPAR-gamma-RXR-nuclear receptor complex on DNA. Nature 2008;456: 350-356.

33 Weber B, Saurer L, Mueller C: Intestinal macrophages: differentiation and involvement in intestinal immunopathologies. Semin Immunopathol 2009;31:171-184.

-34 Sanders TJ, McCarthy NE, Giles EM, Davidson KL, Haltalli ML, Hazell S, Lindsay JO, Stagg AJ: Increased production of retinoic acid by intestinal macrophages contributes to their inflammatory phenotype in patients with Crohn's disease. Gastroenterology 2014; 146:1278.e2-1288.e2.

35 Kamada N, Hisamatsu T, Honda H, Kobayashi T, Chinen H, Kitazume MT, Takayama T, Okamoto S, Koganei K, Sugita A, Kanai T, Hibi T: Human CD14+ macrophages in intestinal lamina propria exhibit potent antigenpresenting ability. J Immunol 2009;183:17241731.

36 Uo M, Hisamatsu T, Miyoshi J, Kaito D, Yoneno K, Kitazume MT, Mori M, Sugita A, Koganei K, Matsuoka K, Kanai T, Hibi T: Mucosal CXCR4+ IgG plasma cells contribute to the pathogenesis of human ulcerative colitis through FcgammaR-mediated CD14 macrophage activation. Gut 2013;62:1734-1744.

37 Kilroy G, Kirk-Ballard H, Carter LE, Floyd ZE: The ubiquitin ligase Siah2 regulates PPARgamma activity in adipocytes. Endocrinology 2012;153:1206-1218.

- 38 Hauser S, Adelmant G, Sarraf P, Wright HM, Mueller E, Spiegelman BM: Degradation of the peroxisome proliferator-activated receptor gamma is linked to ligand-dependent activation. J Biol Chem 2000;275:18527-18533.

39 Mullally JE, Moos PJ, Edes K, Fitzpatrick FA: Cyclopentenone prostaglandins of the J series inhibit the ubiquitin isopeptidase activity of the proteasome pathway. J Biol Chem 2001; 276:30366-30373.

40 Fajas L, Fruchart JC, Auwerx J: PPARgamma3 mRNA: a distinct PPARgamma mRNA subtype transcribed from an independent promoter. FEBS Lett 1998;438:55-60.

41 Olszak T, Neves JF, Dowds CM, Baker K, Glickman J, Davidson NO, Lin CS, Jobin C, Brand S, Sotlar K, Wada K, Katayama K, Nakajima A, Mizuguchi H, Kawasaki K, Nagata K, Muller W, Snapper SB, Schreiber S, Kaser A, Zeissig S, Blumberg RS: Protective mucosal immunity mediated by epithelial CD1d and IL-10. Nature 2014;509:497-502.

42 Gao J, Tao YL, Li G, Yi W, Xia YF: Involvement of difference in decrease of hemoglobin level in poor prognosis of stage I and II nasopharyngeal carcinoma: implication in outcome of radiotherapy. Int J Radiat Oncol Biol Phys 2012;82:1471-1478.

43 Handstad T, Rye M, Mocnik R, Drablos F, Saetrom P: Cell-type specificity of ChIP-predicted transcription factor binding sites. BMC Genomics 2012;13:372.

-44 Alvarez Y, Municio C, Alonso S, Sanchez Crespo M, Fernandez N: The induction of IL-10 by zymosan in dendritic cells depends on CREB activation by the coactivators CREBbinding protein and TORC2 and autocrine PGE2. J Immunol 2009;183:1471-1479.

45 Chanteux H, Guisset AC, Pilette C, Sibille Y: LPS induces IL-10 production by human alveolar macrophages via MAPKinases- and Sp1-dependent mechanisms. Respir Res 2007;8:71.

46 Staples KJ, Smallie T, Williams LM, Foey A, Burke B, Foxwell BM, Ziegler-Heitbrock L: IL-10 induces IL-10 in primary human monocyte-derived macrophages via the transcription factor Stat3. J Immunol 2007;178:47794785.

47 Yang SL, Chen SL, Wu JY, Ho TC, Tsao YP: Pigment epithelium-derived factor induces interleukin-10 expression in human macrophages by induction of PPAR gamma. Life Sci 2010;87:26-35.

48 Hedin CR, Stagg AJ, Whelan K, Lindsay JO: Family studies in Crohn's disease: new horizons in understanding disease pathogenesis, risk and prevention. Gut 2012;61:311-318.

49 Bjarnason I: Intestinal permeability. Gut 1994;35:S18-S22.
TLR4 Mediates PPAR $\gamma$-Dependent IL-10 Production in Human IECs
J Innate Immun 2015;7:87-101 DOI: $10.1159 / 000365417$ 